UDC 32(460.23)(092)

DOI: 10.24919/2519-058x.14.197192

\begin{abstract}
Alina MOZOLEVSKA
PhD (Philology), Head of the Department of Romance and Germanic Philology, Petro Mohyla Black Sea National University, 10 68-Dessantnykiv Street, Mykolaiv, Ukraine, postal code 54003 (alina.shkurat@gmail.com)
\end{abstract}

ORCID: https://orcid.org/0000-0002-1550-8734

\title{
Anastasia KHMEL
}

PhD (History), Associate Professor at the Department of International Relations and Foreign Policy, Petro Mohyla Black Sea National University, 10 68-Dessantnykiv Street, Mykolaiv, Ukraine, postal code 54003 (hmelnastia@ukr.net)

ORCID: https://orcid.org/0000-0002-4881-7859

\section{Аліна МОЗОЛЕВСБКА}

кандидат філологічних наук, завідувач кафедри романо-германської філологї Інституту філології Чорноморського національного університету ім. Петра Могили, вул.68 Десантників, 10, м. Миколаїв, Україна, індекс 54003 (alina.shkurat@gmail.com)

\section{Анастасія ХМЕЛЬ}

кандидат історичних наук, доцент кафедри міжнародних відносин $i$ зовнішньої політики Чорноморського національного університету ім. Петра Могили, вул. 68 Десантників, 10, м. Миколаїв, Україна, індекс 54003 (hmelnastia@ukr.net)

Бібліографічний опис статті: Khmel, A. \& Mozolevska, A. (2020). Catalonia and Catalans in Carles Puigdemont Political Discourse: In Search of National Identity. Skhidnoievropeiskyi Istorychnyi Visnyk [East European Historical Bulletin], 14, 214-224. doi: 10.24919/2519-058x.14.197192

\section{CATALONIA AND CATALANS IN CARLES PUIGDEMONT POLITICAL DISCOURSE: IN SEARCH OF NATIONAL IDENTITY}

\begin{abstract}
The purpose of the paper is to determine the peculiarities of the construction of Catalan identity in C. Puigdemont public speeches in 2016 - 2018. The specificity of the chosen theoretical and methodological model of the research is to involve diverse tools of analysis (critical discourse analysis, linguistics, history, political science and sociology) to study the images of Catalonia and Catalans in the modern Spanish political discourse. The authors assumed that Catalan identity has features of national identity in C. Puigdemont political discourse and is used as one of the leading levers of influence on public opinion. The article defines the historic context and main components of the discursive construction of Catalan identity. For analysis and systematization of information, such methods as historical approach, content and event analysis, discourse analysis and elements of statistical analysis were used. The Scientific Novelty. For the first time it was made an analysis of the role of discursive strategies in the verbalization of Catalan identity in specific texts - in the public speeches of C. Puigdemont, the politician who had a significant impact on the evolution of the Constitutional Crisis in Catalonia in 2017 - 2018. The Conclusions. The analysis allowed to
\end{abstract}


explore the historical context and main mechanisms of the verbalization of the cultural and national values of Catalonia and nationalist ideology in political discourse. We found that C. Puigdemont uses different strategies to achieve his communicative goal and create positive images of Catalonia and Catalans in the minds of his audience. The politician is guided by the strategy of self-identification and self-representation to conceptualize the central images of his political speeches. The strategy of division into "us" and "others" is realized by contrasting Catalan and Spanish identities, as well as by comparing Catalonia and Spain as a higher and dependent, aggressor and victim, oppressor and defender. The polarization of the society and the economic decline of Catalonia can be considered as the effects of the implementation of C. Puigdemont policy.

Key words: Catalonia, Catalans, Spain, Spaniards, political discourse, national identity, discourse analysis, discursive strategy.

\title{
КАТАЛОНІЯ ТА КАТАЛОНЦІ У ПОЛІТИЧНОМУ ДИСКУРСІ К. ПУЧДЕМОНТА: У ПОШУКАХ НАЦІОНАЛЬНОЇ ІДЕНТИЧНОСТІ
}

\begin{abstract}
Анотація. Мета дослідження - визначити специфіку формування каталонської ідентичності у публічних виступах К. Пучдемонта у 2016 - 2018 рр. Специфіка обраної теоретико-методологічної моделі дослідження полягає у залученні комплексу різнопланового інструментарію (досягнення у галузі критичного дискурс-аналізу, лінгвістики, історичній науці, політології та соиіологіï) для аналізу образів Каталонії та каталонців у сучасному політичному просторі Іспанії. Автори висунули гіпотезу дослідження, яка полягає у припущенні, що каталонська ідентичність, яка має ознаки начіональної у політичному дискурсі К. Пучдемонта, використовується як один з провідних важелів впливу на суспільну думку. У статті визначено історичні умови, в яких К. Пучдемонтом було сформовано основні складові каталонської ідентичності в рамках визначених дискурсивних стратегій. Для аналізу і систематизачії інформаиії були використані такі методи, як історичний підхід, контент- та івентаналізи, дискурс-аналіз та елементи статистичного аналізу. Наукова новизна роботи полягає у тому, що вперше в історичному контексті аналізуються дискурсивні стратегї у формуванні ідентичності, які були використані К. Пучдемонтом у публічних виступах. Саме цей політик мав значний вплив на зародження та розгортання Конституиійної кризи у Каталонії у 2017 - 2018 р. Висновки. Під час дослідження автори зазначили історичні умови, які, з одного боку, вплинули на формування механізмів вербалізації культурних та національних иінностей Каталонії та націоналістичної ідеології у політичному дискурсі, а з іншого, слугували плідним тлом для реалізаиії циих механізмів. 3 'ясовано, щзо К. Пучдемонт використовує різні стратегії для досягнення комунікативної мети і створення позитивних образів Каталонії та каталониів у свідомості аудиторії. Політик орієнтується на стратегію самоідентифікації та авторепрезентаиії для концептуалізації центральних образів його політичних промов. Стратегія поділу на "своӥх" та "чужсих" реалізується за допомогою протиставлення каталонської та іспанської ідентичностей, а також за допомогою зіставлення Каталонії і Іспанії як вищого й залежного, агресора і жертви, гнобителя та захисника. Політичними наслідками такого дискурсу можна вважати поляризацію суспільства та економічний спад Каталонії.
\end{abstract}

Ключові слова: Каталонія, каталонці, Іспанія, іспанџі, політичний дискурс, начіональна ідентичність, дискурс-аналіз, дискурсивна стратегія.

The Problem Statement. The historical conditions in which political communication is implemented largely influence the perception of discourse by the audience, which verbalizes the values and historical orientations of society. In our case, political discourse served as a channel of communication between the power representatives and the people, directly participating in the reevaluation of regional and national identities and polarizing society. That is why it is crucial to analyze political discourse, which will allow researchers to identify the main trends of change in the way society thinks and to predict certain ideological transformations. 
The Analysis of Sources and Recent Researches. Let us note, that the problems of Catalan autonomy have attracted the attention of historians (Andrés, 2015; Elliott, 2018; Rogge, 2011), as well as politicians and journalists (in particular Sambio16, Diario16, Nueva sociedad, El Pais, El Mundo, El Periodico, La Vanguardia) who are highlighting the historical background of the 2017 Catalonian crisis and current economic and political problems of the region, although the particularities of political communication during crises remain out of focus of research.

The chosen aspect of identity analysis through the prism of political discourse is resulted from the interest of modern science in the analysis of peculiarities of communication between the power institutions and the people. A lot has been written about the characteristics of political discourse (Butova, 2009, about relation between language, identity and political communication (Wodak, 1989; Zelinskyi, 2018), stylistic peculiarities of political discourse (Muniru Oladayo, 2017), gender aspects of communication in the politics (Nurseitova, 2013).

Contemporary Critical Discourse Analysis has achieved remarkable results in this field explaining how power, language, ideology and national identity are interrelated (T. van Dijk, N. Fairclough, M. Meyer, R. Wodak). Critical Discourse Analysis considers text structures as means of power implementation and generation of new ideologies or sustaining of existing ideologies (Wodak, 2009, p. 8). National identity acts as one of the central elements of the conceptualization of the nation in discourse and as a means of manifestation of power that can separate or unite different ethnic groups and generate/erase borders. Despite the considerable amount of studies devoted to various aspects of the conceptualization of the national identity of different nations (Kutsyi, 2018; Ryazanova-Clarke, 2008; Triandafyllidou, 1998; İnaç, Üna 2013) or to the issue of transnational identity (Hashieva, 2014; Yavorskaya, 2008), the transformation of Catalan identity in the modern historical context remains out of view among researchers and has not been considered in details. The purpose of the article is to apply the achievements of contemporary discourse-analysis to study the process of reshaping of Catalan identity in Carles Puigdemont public speeches.

The Statement of the Basic Material. "The Catalan problem is an irresolvable problem that can only be tolerated", said José Ortega and Gasset in May 1932 during Republican debate (Andrés, 2015). We can only agree with the Spanish thinker of generation "98", and predict the aggravation of relations between the central government of Spain and Catalonia and the further polarization of society. It is known that the Catalan question (the desire for autonomy, and eventually independence), has not appeared today, and dates back more than a century. In Catalonia, the idea of a differentiated linguistic and cultural community has its historical traditions since XVIII century. Today we are witnessing the stage of exacerbation of this problem, which is connected not only with the historical confrontation between Catalan and Spanish nationalism, but also with the triple crisis (economic, political and territorial) that Spain has been experiencing since 2007 (Serra, González, Martí and Puig, 2018) In fact, these circumstances have provided a wonderful background for the propagation of nationalist policy of C. Puigdemont. The situation was aggravated by the state of Catalan society: "We live in a politics of fear ... Yes, when the society is shocked, it is very easily with it, if it is a bubble. And Catalonia is the perfect tool to use such policy" (Andrés, 2015).

The decision to analyze C. Puigdemont public speeches can be explained by the fact that this politician not only promoted the Catalan national idea and held a referendum on independence against the will of Spanish authorities, but, unlike his predecessor Artur Mas, managed to proclaim the Declaration of Independence of Catalonia on the results of this referendum (at least $90 \%$ of participants supported the independence of Catalonia but the turnout was only 42,3\%). Carles Puigdemont is a Spanish journalist and politician who was the President of the Generalitat de Catalunya from 2016 
to 2017 and the Mayor of Gerona from 2011 to 2016. As a journalist he worked at El Punt (joined in 1982), Agéncia Catalana de Notícies (1999 - 2002), Casa de Cultura de Girona (2002 - 2004), Catalonia Today (2004 - 2006). During his presidency, the Generalitat held a referendum on the independence of Catalonia, which provoked the Constitutional crisis in Spain and led to special elections in Catalonia. On October 28, 2017, the Senate of Spain invoked article 155 of the Constitution and dismissed C. Puigdemont together with the Catalan government and imposed direct rule on Catalonia. The charges of rebellion and misuse of public funds at the Audiencia Nacional were laid against C. Puigdemont (El poder judicial, 21/03/2018). On March 25, 2018, C. Puigdemont was arrested in Germany, and on April 5, German justice released him on bail (La vanguardia, 06/04/2018). On October 4, 2019, the Spanish Supreme Court sentenced him to 13 years in prison and issued an international arrest warrant, but the Belgian Court suspended the deportation order to Spain because of his immunity as a Member of the European Parliament.

Considering the historical context, we assume that in the discourse of C. Puigdemont, Catalan identity is verbalized as an element of national consciousness, rather than a regional one. Accordingly to this, the politician must use specific discursive strategies that polarize the idea of the Catalans about themselves and others and contribute to the differentiation of Catalan identity from other nations. The principle of sameness and difference, which is considered as one of the main principles of construction of national identity (Wodak, 2009, p. 26), is realized through the verbalization of a positive self-image ("us") and the negative image of "others". In the discursive space of politician, the ethno-cultural group of Catalans, the group of "us" is united geographically and ethnically. The group of "others" is associated with the population of Spain in other regions and representatives of the Spanish Government.

For the organization of the research, the authors passed three stages. In the first stage, the authors put forward the main hypothesis of the study and identified the range of issues to be analyzed. We hypothesized that the Catalan identity has features of national identity in the political discourse of C. Puigdemont. This assumption is based on his political views and oh his desire to gain Catalan independence from the Spanish monarchy. In our opinion, C. Puigdemont used his public speeches to form nationalistic mood among the population of Catalonia, using the idea of Catalan identity as one of the means of influence on public opinion.

In the second stage, the chronological boundaries of the texts for analysis were determined, and the achievements of foreign scientists were analyzed to supplement the research tools of our research. Therefore, these actions comprised the Information Search.

The third stage consisted of analysis, processing and systematization of the information and the formulation of conclusions. The authors used such political methods as content and event analysis, through which the authors identified C. Puigdemont's vision of Catalans as a nation. The study also used the method of discourse analysis and the elements of statistical analysis to determine the frequency of the use of key concepts for the identity verbalization.

The corpora comprise the public speeches of C. Puigdemont from May 2016 to March 2018 (40,000 words, the access to the texts http://www.president.cat/pres_gov/president/ca/ president/discursos.html). The time frame can be explained by historical events in Catalonia. We start our analysis with the year 2016 because this year C. Puigdemont became the President and started to promote his ideas. And we finish with the year 2018 as on March 25, 2018, C. Puigdemont was arrested in Germany.

First of all, we need to clarify the concept of "identity" and define the strategies for its construction in the discourse. The term "identity" is studied in many sciences and several types of identities can be singled out: cultural, social, national, civic, gender, ethno-religious 
identity. Of course, in everyday life it's difficult to distinguish these types of identities one from one another as they intersect creating circles, similar to the Venn diagram. Therefore, there is no single viewpoint on this socio-political phenomenon among scholars.

The same situation can be observed with the term "national identity" which is commonly used by ordinary citizens and politicians of any country. Despite the intensive use of this notion, the researchers are still trying to define the national identity, to single out its components and to answer the question whether one can manipulate a person through its national self-image and consciousness. The degree of belonging/unbelonging of person to a nation affects the level of internal and external security of the state. In the twenty-first century, the danger of the erosion of nations and the formation of new states is still present that can lead to the destabilization of international relations. Thus, the analysis of conceptualization of national identity in different types of discourse represents a particular interest and, in our case, the study of discursive strategies used in C. Puigdemont speeches to separate the identities of Spaniards and Catalans enriches the contemporary, scientific ways of understanding of the notion "national identity".

Regarding the definition of "national identity", Ukrainian researcher L. Loyko notes that in the history of our socio-political thought it is possible to trace different approaches to understanding of this notion that single out either the ethno-cultural, or the national-public component. In the opinion of modern Ukrainian scholars, national identity is not an innate trait of the nation, but the result of implementation of social and cultural practices, civil and political traditions, the development of institutional, economic and social space. Under certain circumstances national identity can become the driving force of socio-political transformations. According to L. Loyko, not the nation itself but ideologists proclaim the unity of the nation basing on the common history of the ethnos, common culture and religion (Loyko, 2011). In other words, the national self-identification is a result of "national agitation". The propaganda and consolidation of the nation by the cultural elite and politicians are extremely necessary for the creation of national identity. Politicians can also play a destructive role and split the nation. We will try to determine the role played by C. Puigdemont in this process.

In the framework of our study, we define the national identity as a social level of self-identification, characterized by "the sense of belonging to a community that recognizes itself as a nation" (Morris, 1995, p. 14). Thus, the members of a certain ethnic group are aware of their uniqueness and difference from others, which is realized through comparing themselves to other ethnic groups. This sense of belonging is generated by a variety of social practices that ensure the territorial and ethnic integrity of the nation. Considering this idea, Catalan identity in C. Puigdemont political discourse may also contribute to the generation of nationalist moods in the region, since, according to contemporary theories of nationalism, identity, and not ideology, plays a leading role in the formation of the latest nationalist movements (see, for example, Michael Billig, Banal Nationalism (London; Thousand Oaks, Calif.: Sage, 1995). Thus, identity as an element of the discursive space of political communication of C. Puigdemont may be understood as a discursive object and as a means of impact on the public consciousness. Let us consider the means of conceptualization of Catalan identity in the discursive space.

In public speeches of the politician, the process of identity construction is implemented through several discursive strategies. We understand the strategy after R. Wodak as "a more or less precise plan that is being implemented to achieve a certain political, psychological or other goal" (Wodak, 2009, p. 31). The politician as the President of Catalonia addresses his audience mostly in Catalan. The language choice is not accidental. The Catalan language is inseparable from the identity dimension, and the politician chooses this linguistic strategy to 
emphasize his belonging to the Catalan people. Although there may be exceptions in some cases. For example, in his speech of October 4, 2017 C. Puigdemont resorts to the language code switching: “...Seguim un camí democràticament marcat per la voluntat dels ciutadans, i això enlloc de ser combatut hauria de començar a ser comprès i a ser respectat. Por eso quiero dirigirme a los ciudadanos españoles que en estos días han expresado su compromiso con las demandas de los catalanes; ciudadanos que nos han enviado su amistad y su solidaridad muy valiosa en los momentos que estamos viviendo..." (Puigdemont, 4/10/2017) (underlining is ours. - author). In this example, C. Puigdemont delivers a part of his speech in Spanish and emphasizes that he is referring to the Spaniards and not to the Catalans. The Castilian language is associated with Spain, while the politician communicates with the citizens of Catalonia in Catalan. Thus, already on the linguistic level, the implementation of the macrostrategy of division (opposition of "us" and "others") can be traced. In the discursive space of C. Puigdemont, the macrostrategy of division is also realized through the implementation of several other strategies - the strategy of conceptualization of the image of Catalonia, of positive presentation of "us", of negative presentation of "others", of idealization of Catalonia and Catalans, of demonizing "other". Let us consider each of the strategies in more detail.

The central element of the conceptualization of Catalan identity is the verbalization of the image of Catalonia. In the discourse this strategy focuses on the representation of Catalonia as a complex ethnic and national formation characterized by exceptional individual characteristics. The nominations "Catalunya", "los Catalans" and "el poble de Catalunya" are used very frequently as well as phrases such as "ciutadans de catalunya, la societat catalana, el Govern de Catalunya, el Parlament de Catalunya, les infrastructures de Catalunya, les autoritats catalanes, la legalitat catalan, les institucions dels Catalans".

The appeal to the Catalans as a single nation ("nostre país, los Catalans, ciutadans de Catalunya") and the identification of Catalonia with its population contribute to the consolidation of the citizens and helps to create a common desire for independence. The use of the names of various power institutions is intended to give the impression of Catalonia as a self-sufficient country with all the features of an independent state. We have been able to identify the main language units that conceptualize the image of Catalonia with the help of the statistical analysis of key words (Table 1).

Table 1

Verbal images of conceptualization of Catalonia

\begin{tabular}{|c|c|}
\hline Important verbal images & Number \\
\hline Catalunya & 348 \\
\hline nostre país & 25 \\
\hline los Catalans & 66 \\
\hline ciutadans de Catalunya & 11 \\
\hline la societat catalana & 11 \\
\hline el poble (català $\backslash$ de Catalunya) & 22 \\
\hline nostra nació & 10 \\
\hline l'economia catalana $\backslash$ nostra economia & 14 \\
\hline llengua & 8 \\
\hline cultura catalana & 4 \\
\hline ciutadans i ciutadanes & 3 \\
\hline
\end{tabular}


As we can see, the main images used by the politician are related to key components of the identity - cultural and geographical integrity, ethnic and national uniqueness, economic independence. The politician tries to present Catalonia as a region that has its own language, its own culture and its own lifestyle: “... la llengua, la cultura i la manera de ser i de viure del nostre país" (Puigdemont, 10/20/2017). Such a positive vision of Catalonia and, to a certain extent, the idealization of the image of the region aims to prove the maturity of Catalan national identity and the right to establish an independent sovereign country.

The conceptualization of the image of Catalonia is also realized in temporal dimension. Catalonia is verbalized as a region with centuries-old history of the nation's creation (“...la voluntat de convocar els ciutadans i ciutadanes del nostre país, en exercici del legítim dret a l'autodeterminació que té una nació millenària com Catalunya..." (Puigdemont, 09/06/2017) where people are aware of their uniqueness and rich cultural heritage of the country («Somos un solo pueblo, que ama las lenguas que habla, que no tiene ningún problema con las identidades, las nacionalidades y las culturas...» (Puigdemont, 4/10/17). The positive vision of the future of the region and the focus on shaping the vivid image of independent Catalonia contributes to the idealization of the image of the country and reinforces the influence on the audience.

In addition, according to the results of analysis, C. Puigdemont sees in Catalonia a highly developed industrial zone, which serves as the basis for the progress of the entire country. Catalonia is portrayed as a region that differs not only in cultural and ethnic dimension but also in terms of economic progress. We can illustrate our generalizations with following examples: "Catalunya ha estat no només el motor econòmic d'Espanya, sinó també un factor de modernització i d'estabilitat" (Puigdemont,10/10/2017), “...Catalunya creix, Catalunya exporta, Catalunya atrau inversions, Catalunya crea riquesa" (Puigdemont, 14/06/2017) (underlining is ours. - author). Such strategic vision of Catalonia is justified as this region produces $20 \%$ of GDP of the country and comprises only $16 \%$ of the population of Spain. It's true that Catalonia is fourth in terms of investments among the Euroregions, every third Spanish exporter is Catalan, and 1\% of the world's scientific publications are written by Catalans (data available at the site of Generalitat de Catalunya, http://economia.gencat.cat). As a result, the idea of superiority of Catalonia over other Spanish regions is supported by real facts and peculiarities of the regional development.

As we see, the vision of Catalonia in C. Puigdemont speeches has a geographical, institutional, temporal and economic dimension. Catalonia is verbalized as an element of Catalan identity and a symbol of the fulfillment of the Catalan aspirations for self-identification: "Catalunya sempre defensa i porta molts anys defensant la seva identitat i els seus interessos nacionals. I passi el que passi ho continuarà fent, perquè aquesta és la característica del nostre poble i de la nostra nació" (Puigdemont, 16/01/2017). It is also represented as the guarantor of the nation's security: “Catalunya és una nació que protegeix tots els seus ciutadans, sense excepció" (Puigdemont, 5/10/2016). The idealization of Catalonia contributes to enhancing the sense of uniqueness and intensifying the desire for independence.

The strategy of positive representation is also used to verbalize the image of the Catalan people. In the discursive space of politician, the Catalans are described as people united by common aspirations: "Una vegada més, el poble de Catalunya va demostrar ahir que està unit, que és un sol poble, que fa pinya en la defensa dels valors de la democràcia..." (Puigdemont, 4/10/201) (underlining is ours. - author). According to C. Puigdemont, Catalans are a free community (“...és ... una nova era de la història de Catalunya; l'era d'una 
Catalunya lliure" (Puigdemont, 16/01/2017»), peaceful (“Som gent de pau, ho hem demostrat en totes les occasions" (Puigdemont, 1/03/2018) and respectful to the cultural diversity of others ("Somos, en efecto, una sociedad enormemente congregation en la diversidad" (Puigdemont, 10/4/2018). The generalization of positive features creates a unified image of "us", which is intended to unite all Catalans.

At the same time, we can trace the tendency towards the victimization of the Catalans. They are portrayed as victims of the policy of the Spanish government, which, according to C. Puigdemont, does not respect the right to vote and the right to freedom of expression of Catalonia's citizens: “...els catalans que han estat víctimes d'una violència policial que ha glaçat el cor a mig món" (Puigdemont, 4/10/2017). The politician thinks that the people must find strength to defend their rights because they have the will to decide their future ("la voluntat del nostre poble de decidir el seu future" (Puigdemont, 1/03/2018). It should be noted that the victimization as a part of the strategy of self-presentation is able to unite the nation against a common enemy and to make it stronger and more decisive.

Another strategy used by C. Puigdemont is the strategy of division. This strategy is realized through the opposition between the image of Catalonia and Catalan people and other nations with the aim to present Catalonia as a separate country/nation. This is where the regional identity is transformed into the national identity. The most explicit is the opposition between Spain ("other") and Catalonia. Spain and its state institutions are shown as hostile forces that hold back the Catalans' desire for independence. Firstly, C. Puigdemont, defines the relations between Catalonia and Spain as the main source of conflict: "Creiem que la millor manera de saber quin projecte gaudeix de més suports (la permanència a Espanya o la creació d'un estat) és votant. Davant d'un conflicte polític -pacífic- entre Catalunya i Espanya..." (Puigdemont, 24/01/2017) (underlining is ours. - author). According to the politician, this conflict is the reason why the Catalans are not able to fulfill their aspirations, as the Spanish monarchy implements the policy of occupation and restriction in relation to Catalonia. The root of the conflict is seen in the reluctance of the Spanish government to recognize the rights of the Catalans to decide their future: "...la defensa de la legitimitat i la legalitat catalanes injustament i il·legalment atacades per l'Estat espanyol, que continua negant-se a acceptar la voluntat dels Catalans" (Puigdemont, 1/03/2018) (underlining is ours. author). Here we can also trace the tendency towards the victimization of Catalans who can not speak freely. In this case the Government of Spain is portrayed as aggressor, the source of all kinds of violence: "els altres posen violència policial, judicial i econòmica" (Puigdemont, 1/03/2018). In addition, the politician claims that the Government of Spain pursue the policy of occupation and ignores Catalan's voice: “Ara Madrid no hi tindrà cap excusa per continuar la seva política d'ocupació. No hi haurà cap excusa perquè Madrid ignori la nostra veu, o que no accepti les nostres decisions, o que imposi una visió colonialista sobre el nostre futur" (Puigdemont, 1/03/2018) (underlining is ours. - author). It is worth noting that the Catalans are shown not as passive victims of the conflict but as active actors who resist the aggression and try to overcome injustice: “...perquè hem de defensar el dret dels catalans a decidir el seu futur. Davant de la covardia dels qui usen la violència i els recursos de manera illimitada de l'Estat m'admira i m'emociona la valentia dels milers de ciutadans que estan defensant les urnes i estant defensant els collegis electorals perquè la gent pugui participar" (Puigdemont, 1/10/2017) (underlining is ours. - author).

To dramatize the conflict situation and strengthen the image of Catalonia as a victim, the politician also mentions not only the violations of national values, but also violations of family 
and individual values. In this way C. Puigdemont tries to raise awareness of issue in Catalonia among wider audience: "Han fet mal a persones i famílies, i sobretot han fet mal a tots els catalans tallant en sec polítiques i inversions en àmbits com el social, el cultural i l'econòmic només, només, per castigar un poble que ha gosat exercir un dret que és reconegut a tots els pobles del món per la Carta dels Drets Civils i Polítics de les Nacions Unides" (Puigdemont, 1/03/2018). Here, C. Puigdemont focuses his attention on the victims of the Spanish policy, simple people suffering from social, economic and cultural oppression. The motivation of the Spanish government is shown rather brutallythey want to punish people who dared to exercise their legitimate rights. Such vision of Spain as aggressor state is even more intense in comparison with the positive image of Catalonia and the Catalans, the peace-loving people ("gent de pau"). At the same time, the politician is trying to justify the situation in Catalonia: "No Somos unos delincuentes, ni Unos locos, ni Unos golpistas, ni Unos abducidos: somos gente normal que pide poder votary que ha estado dispuesta a todo el dialogo que Fuera Necesario para realizarlo de manera acordada" (Puigdemont, 10/10/2017).

It has to be pointed out that in the discourse of C. Puigdemont the main hostile forces are not Spaniards as a nation, but the state structures of the Spanish state ("el Govern espanyol, l'Estat espanyol, el sistema polític espanyol, les institucions espanyoles"). They are the main source of unlawful acts and violence against the Catalans. Despite the fact that Catalan identity is being realized through denial of belonging to the Spanish nation and affirmation of differentness, there are still no accusations against the Spaniards in the speeches. The desire to consolidate two ethnic groups and the attempt to bring compassion for the simple Spaniards to the Catalan people can be traced in the discourse of C. Puigdemont.

In general, our analysis helped distinguish several oppositions between Catalonia and Spain that depict the confrontation between the autonomous region and the Spanish state (Table 2):

Table 2

Main verbal oppositions between Spain and Catalonia

\begin{tabular}{|l|l|}
\hline \multicolumn{1}{|c|}{ l'Estat espanyol / Madrid } & \multicolumn{1}{c|}{ Catalunya /la república catalana } \\
\hline $\begin{array}{l}\text { oppressor } \\
\text { imperfect institutional system } \\
\text { supervised freedom }\end{array}$ & $\begin{array}{l}\text { victim } \\
\text { state of law and justice } \\
\text { republic of free men and women }\end{array}$ \\
\hline $\begin{array}{l}\text { unfair } \\
\text { hostile } \\
\text { violent / cruel } \\
\text { intransigent }\end{array}$ & $\begin{array}{l}\text { peaceful } \\
\text { democratic } \\
\text { civil } \\
\text { brave }\end{array}$ \\
\hline $\begin{array}{l}\text { commits abuses } \\
\text { occupies illegitimately } \\
\text { criminalizes the ideology } \\
\text { applies the political offensive } \\
\text { ignores the voice of the Catalans } \\
\text { introduces tension in Catalan society }\end{array}$ & $\begin{array}{l}\text { denounces and prosecutes abuses } \\
\text { defends the people } \\
\text { wants to express freely } \\
\text { wants to build a decent future }\end{array}$ \\
\hline
\end{tabular}

We can observe that "l'Estat Espanyol" is portrayed as formation that incarnate all the negative features and is very violent towards Catalonia. These key oppositions contribute to the construction of the negative image of the "other" demonizing it to some extent.

The Conclusions. The authors found that Catalonia issue dates back more than a hundred years and escalated at the beginning of the 21 st century, which was connected to the economic, 
political and territorial crisis in Spain. The construction of the national identity of Catalans in C. Puigdemont speeches took place under difficult historical conditions, which influenced the Catalans' positive reaction to nationalistic discourse of the politician.

The analysis allowed us to explore the mechanisms of the verbalization of the cultural and national values of Catalonia and nationalist ideology in political discourse. We found out that C. Puigdemont uses different strategies to achieve his communicative goal and create positive images of Catalonia and Catalans in the minds of his audience. The politician is guided by strategies of self-identification and auto representation to conceptualize the central images of his political speeches. The strategy of division into "us" and "others" is realized through the opposition of the Catalan and Spanish identities, as well as comparison of Catalonia and Spain as a superior power and dependent agent, aggressor and victim, oppressor and defender. It should be noted that the image of the Spanish state and the Spanish people is built differently. Catalonia opposes to the Spanish state as a hostile and unfair organization, there is no direct opposition between the Spaniards and Catalans. With the help of combination of discursive strategies and the use of contrast images of Spain and Catalonia, C. Puigdemont succeeded to idealize his country and his people on the one hand and demonize the image of Spain on the other hand.

Regarding the political consequences of such discourse, we can note that the politician divided not only the Spanish society (Spaniards and Catalans), but also created discord among the Catalans themselves. This is evidenced by the fact that only small part of the Catalans came to a referendum and voted, thus, the will was revealed by a minority. However, the Declaration of Independence of Catalonia was proclaimed and the conflict between the central Spanish authorities and the autonomous government of Catalonia escalated and continues to this day. Consequently, C. Puigdemont succeeded to unite with his speeches only a part of the Catalans and people were divided by the idea of independence. In addition to such a division of society, Catalonia has also received an economic downturn for several years. As we see, the polarization of society and the economic downturn of Catalonia can be considered as consequence of $\mathrm{C}$. Puigdemont political discourse on Catalan identity and political strategy.

By the perspective of the study, we consider expanding the analysis of Catalan identity conceptualization in the political discourse by the study of public speeches of the representatives of Spanish central government.

Acknowledgments. The authors of the publication express the sincere gratitude to the Petro Mohyla Black Sea National University for the support and assistance in the research.

Funding. The authors received no financial support for the research, authorship, and/or publication of this article.

\section{BIBLIOGRAPHY}

Butova, I. (2009). Politychnyy dyskurs yak ob'yekt linhvistychnykh doslidzhen' [Political discourse as an object of linguistic research]. Visnyk L'vivs'koho universytetu - Inozemni movy. Visnyk of Lviv University - Foreign Languages, 16, 232-237. [in Ukrainian]

El juez Pablo Llarena procesa por un delito de rebelión a 13 de los investigados en la causa por el proceso secesionista de Cataluña (2018). [Judge Pablo Llarena prosecutes 13 of those investigated in the case for the secessionist process of Catalonia for a crime of rebellion]. URL: http://www.poderjudicial. es/cgpj/es/Poder-Judicial/Noticias-Judiciales/El-juez-Pablo-Llarena-procesa-por-un-delito-de-rebeliona-13-de-los-investigados-en-la-causa-por-el-proceso-secesionista-de-Cataluna [in Spanish]

Elliott, J. H. (2018). Scots and Catalans: Union and Disunion. New Haven and London: Yale University Press, 360 p. [in English] 
Gil de Andrés, C. (2015). La cuestión catalana, historia y politica [Catalonia issue, history and politics]. URL: https://www.cambio16.com/la-cuestion-catalana-historia-y-politica/) [in Spanish]

Hashieva, L. V. (2014). Yevropeys'ka identychnist' yak chynnyk yevrointehratsiyi: obyednana Yevropa chy Yevropa natsiy [European identity as a factor of European integration: a united Europe or a nation of Europe]. Teoriya ta praktyka derzhavnoho upravlinnya - The theory and practice of public administration, 3(46), 239-244. [in Ukrainian]

İnaç, H. \& Üna F. (2013). The Construction of National Identity in Modern Times: Theoretical Perspective. International Journal of Humanities and Social Science, 3 (11), 223-232. [in English]

Kutsyi, I. (2018). The reception of Europe/West in the scientific heritage of Mykhailo Maksymovych. Skhidnoyevropeys'kyy istorychnyy visnyk. Vypusk. - Eastern European Historical Bulletin, 7, 8-15. doi 10.24919/2519-058x.7.132753 [in English]

La Justicia alemana deja en libertad a Puigdemont y descarta el delito de rebelión [German Justice releases Puigdemont and dismisses the crime of rebellion]. URL: https:/www.lavanguardia.com/ politica/20180405/442207871883/puigdemont-libre-descarta-rebelion.html [in Spanish]

Loyko, L. (2011). Natsional'na identychnist': Problemy Definitsiy ta polityko-pravovoho zabezpechennya. [National identity: problems of definition and political-legal protection]. URL: http:// social-science.com.ua/article/424 [in Ukrainian].

Morris, N. (1995). Culture, Politics, and Identity. Westport, Conn.: Praeger, 224 p. [in English]

Nurseitova, K., Zharkynbekova, S., Bokayev, B. \& Bokayeva, A. (2013). Language and Gender in Political Discourse (Mass Media Interviews). Procedia - Social and Behavioral Sciences, 70, 417-422. doi: 10.1016/j.sbspro.2013.01.079 [in English]

Oladayo, M. M. (2017). Persuading and Defending: A Stylistic Analysis of Obama's Speech atHiroshima Peace Park on May 27, 2016. International Journal of Language and Literature, 5 (2), 114-120. doi: 10.15640/ijll.v5n2a12. [in English]

Rogge, J. (Ed.). (2011). Cultural History in Europe: Institutions - Themes - Perspectives. Majuskel Medienproduktion GmbH, Wetzlar, 259 p. [in English]

Ryazanova-Clarke, L. (2008). Putin's Nation: Discursive Construction of National Identity in 'Direct Line with President'. In A. Mustayoki, \& M. Kopotev (Eds.), Instrumentariy russistiki: korpusnye podkhody - Instruments of Russian Studies: corpora approaches. Vol. Slavica Helsingiensia, 34, 311-331. [in English]

Serra M., González G. U. \& Martí i Puig S. (2018). Cataluña y la triple crisis española [Canalina and triple Spanish crisis]. NUSO $N^{\circ} 273$ / enero - febrero. URL: https://nuso.org/articulo/catalunay-la-triple-crisis-espanola/ [in Spanish]

Triandafyllidou, A. (1998). National identity and the "other". Ethnic and Racial Studies, 21 (4), 593-612. doi: 10.1080/014198798329784 [in English]

Wodak, R. (Ed.). (1989). Language, Power and Ideology: Studies in political discourse (Critical Theory). Amsterdam: John Benjamins Publishing Company, 308 p. [in English]

Wodak, R., De Cillia, R., Reisigl, M., Liebhart, K., \& Hirsch, A. (trans.), Mitten, R., (trans.), \& Unger, J. W., (trans.) (2009). The Discursive Construction of National Identity. (2nd ed.). Edinburgh: Edinburgh University Press, 276 p. [in English]

Yavorskaya, G. M. (2008). Do problemy formuvanni yevropeys'koyi identychnosti v Ukrayini [To the Problem of Formation of European Identity in Ukraine]. IPiEND im. I. F. Kurasa NAN Ukrayiny Naukovi Zapysk - PIDID them. I.F. Kuras, 42, 269-276. [in Ukrainian]

Zelinskyi, M. (2018). Ukrayina i ukrayintsi v politychniy dumtsi Yoakhima Bartoshevycha (1867 - 1938) [Ukraine and the ukrainians in Joachim Bartoszewicz' political thought of (1867 1938)]. Skhidnoyevropeys'kyy istorychnyy visnyk - East European Historical Bulletin, 6, 86-94. doi: 10.24919/2519-058x.6.124679. [in Ukrainian]

The article was received on May 12, 2019. Article recommended for publishing 26/02/2020. 